\title{
Efficacy and Stability of Scorpion Antivenom: At Different Storage Conditions
}

Elhag DE* and Mahmoud RAK

Institute of Research, UMST University, Khartoum, Sudan

\begin{abstract}
The aim of this study was to investigate the efficacy and stability of scorpion antivenom brand. Several tests were applied on scorpion antivenom samples obtained from the same batch. The samples were subdivided into two groups. The first group was stored at real storage conditions i.e. at $\left(3 \pm 2{ }^{\circ} \mathrm{C}\right)$ dry storage areas while the second group was subjected to accelerated storage conditions i.e. $\left(25 \pm 3^{\circ} \mathrm{C}, \mathrm{RH} 75 \%\right)$. Many samples taken from both conditions were tested chemically through determining the $\mathrm{pH}$ values, $\mathrm{m}$-cresol preservative levels, albumin content by polyacryl amide gel electrophoresis (PAGE) and measuring the protein content. These samples were also tested pharmacologically for determining the potency, measuring the LD50 (lethal dose which kills $50 \%$ of the test animals), pyrogen testing, sterility testing and abnormal toxicity. The results obtained from both chemical and pharmacological tests using antivenom samples stored at real time storage condition $\left(3 \pm 2^{\circ} \mathrm{C}\right)$ and accelerated storage condition $(25$ $\pm 3^{\circ} \mathrm{C}, \mathrm{RH} 75 \%$ ) showed no significant changes in terms of potency, $\mathrm{pH}$ values, sterility, preservative content, the pharmacological effect and efficacy.
\end{abstract}

\section{Keywords: Antivenom; Stability; Toxicity}

\section{Introduction}

Scorpion bites is an actual public health problem in several parts of the world because, either incidence, or severity of envenomations is high and managed with difficulty by health services, or for these two reasons at the same time. Many potentially dangerous scorpions inhabit the under developed or developing countries and numerous envenomations go unreported. Officially, it has been estimated that there are 1.2 million scorpion stings per year around the world leading to 3250 deaths (0.27\%). The 2014 Annual Report of the American Association of Poison Control Centers' National Poison Data System (NPDS) reported 16,440 case mentions for scorpion envenomations. However, because of underreporting, this is probably an underestimation of the true number of stings [1-4]

Scorpion venoms contain many bioactive components. Several of the long-chain peptides were shown to be responsible for neurotoxic effects. These toxins are basic polypeptides with molecular weights of approximately $7,000 \mathrm{kD}$, without enzymatic action and have been shown to affect the ion permeability of excitable cells [5-11].

Scorpion antivenom immunoglobulin's (antivenom) is the only specific treatment for envenoming by scorpion bites. Antivenom can prevent or reverse most of the scorpion envenoming effects, and play a crucial role in minimizing mortality and morbidity. These preparations are included in the WHO List of Essential Medicines and should be part of any primary health care package where scorpion bites occur [12-14].

The antivenom is produced by milking venom from the desired Scorpion, injecting the milked venom into a horse, sheep, rabbit, or goat to stimulate animal immune system. The subject animal will undergo an immune response to the venom, producing antibodies against the venom's active molecule which can then be harvested from the animal's blood and used to treat envenomation. Internationally, antivenoms must conform to the standards of pharmacopoeia and the World Health Organization (WHO).

Currently, there is an urgent need to ensure availability of safe, effective and affordable antivenom, particularly to those in developing countries and to improve the regulatory control over the manufacture, import and sale of antivenom $[3,15,16]$.
Scorpion venom contains neurotoxic peptides that interact with ion channels leading to massive damage to nervous system. Through this interaction, scorpion venom can cause excitation of the nerve and muscle, hormonal secretion, and disturbance in the control of salt and water balance and regulation of blood pressure $[9,17-19]$.

The clinical symptoms upon envenomation indicate a general stimulation of the autonomic, somatic and peripheral nervous systems. The severity of scorpion envenomation and the increased risk of mortality, especially among children, are mainly attributed to cardiorespiratory pathology $[15,20]$.

\section{Materials and Reagents}

\section{Chemical tests}

Determination of $\mathbf{p H}$ : The $\mathrm{pH}$ of the selected samples was measured using an appropriate $\mathrm{pH}$ meter calibrated just before use against standard buffer solutions ( $\mathrm{pH} 4$ and $\mathrm{pH} 7$ ). WHO requirement to produce antivenoms stated the $\mathrm{pH}$ of the antivenom product should be in the range of 6-7.

\section{Determination of m-cresol:}

\section{Preparation of the buffer solution $\mathrm{pH} 9$}

Solution A: 6.18 gm of Boric and 7.45 g potassium chloride $(0.1 \mathrm{M})$ to be dissolved in $1000 \mathrm{ml}$ water.

Solution B: $0.1 \mathrm{~N}$ sodium hydroxide R.

To $1000 \mathrm{ml}$ solution A, $400 \mathrm{ml}$ solution B was added, sodium hydroxide was added gradually to the mixture until $\mathrm{pH} 9$ is reached.

*Corresponding author: Elhag DE, Institute of Research, UMST University, Khartoum, Sudan, Tel: +249 183 228614; E-mail: magied20@gmail.com

Received September 27, 2017; Accepted December 21, 2017; Published December 28,2017

Citation: Elhag DE, Mahmoud RAK (2017) Efficacy and Stability of Scorpion Antivenom: At Different Storage Conditions. Pharm Anal Acta 8: 570. doi: 10.4172/2153-2435.1000570

Copyright: ( 2017 Elhag DE, et al. This is an open-access article distributed unde the terms of the Creative Commons Attribution License, which permits unrestricted use, distribution, and reproduction in any medium, provided the original author and source are credited. 


\section{Potassium ferricyanide solution}

Exactly $5 \mathrm{gm}$ of potassium ferricyanide was washed with $3 \mathrm{ml}$ water then dissolved and diluted with water up to $100 \mathrm{ml}$ (this preparation was prepared immediately before use).

Aminoantipyrine solution R: $100 \mathrm{mg}$ of aminoantipyrine was dissolved in $100 \mathrm{ml}$ buffer solution $\mathrm{pH} 9$.

\section{Preparation of the sample}

Two test groups were prepared. The first group consists of six antivenom ampoules which were selected randomly from the batch of scorpion antivenom stored in real conditions $\left(3 \pm 2^{\circ} \mathrm{C}\right)$. The second group which consists of six antivenom ampoules were subjected to accelerated conditions $\left(25 \pm 3^{\circ} \mathrm{C}, \mathrm{RH} 75 \%\right) .0 .2 \mathrm{ml}$ of each sample (contains up to $0.35 \%$ of $\mathrm{m}$-cresol) was diluted to $3.5 \mathrm{ml}$ water to give a final concentration of $(200 \mu \mathrm{g} / \mathrm{ml})$.

\section{Procedure}

A total of seven beakers were labeled to be used, the first was set as a blank. Six other beakers $0.5 \mathrm{ml}$ of the prepared samples was added to each beaker. Then $5 \mathrm{ml}$ of aminoantipyrine and $5 \mathrm{ml}$ of potassium ferricyanide were added to each beaker successively. The prepared test samples were left for 10 minutes at room temperature then each sample absorbance was measured at $540 \mathrm{~nm}$ using a UV/vis spectrophotometer.

\section{Standard m-cresol preparation}

M-Cresol Solution $(250 \mu \mathrm{g} / \mathrm{ml})$ stock solution was prepared by weighing exactly $1 \mathrm{gm} \mathrm{m}$-cresol and transferring it to 1 litre volumetric flask and the volume was made to the mark by using distilled water. Exactly $2.5 \mathrm{~mL}$ were taken and completed to $10 \mathrm{~mL}$.

A series of appropriate dilution were made to construct the calibration curve and the sample concentrations were determined from the calibration curve.

Determination of the total protein content/ determination of Albumin content: The antivenom solution was diluted with $25 \%$ sucrose solution in $0.01 \mathrm{M}$ phosphate buffer, $\mathrm{pH} 7$, to a protein content of $10 \mathrm{mg} / \mathrm{ml} .10 \mu \mathrm{l}$ samples of the antivenom solution were applied to polyacrylamide gel membranes in the separation chamber and electrophoresed. A standard sample of albumin $1 \mathrm{mg} / \mathrm{ml}$ was run simultaneously with antivenom samples. The gel was then removed from the separation chamber and placed in the developing chamber and development was carried out using the same machine according to the following programmed method. The electrophoretic mobilities of the antivenom and albumin were compared following staining with Coomassie blue.

\section{Pharmacological tests}

These Tests are performed on either Albino white male mice $(20 \pm$ $0.1 \mathrm{gm}$ ) or adult albino (New Zealand rabbits) of either sex weighing 2-3.5 kg that are obtained from the Experimental Animal Unit. The animal was kept at an ambient temperature and given free access to food and water.

Determination of LD50: Mice were divided into different sets to determine intravenous doses that would kill $50 \%$ of the animals (LD 50). Each set (comprised 10 animals) was injected intravenously via the tail with one of the following doses: $(0.15,0.175,0.2,0.225,0.25$, $0.275,0.3$, or $0.325 \mathrm{mg} \mathrm{kg}^{-1}$ ) from Lq scorpion venom. The signs and symptoms of envenomation as well as the number of dead animals after 24 hours were recorded in each group. The LD 50 is calculated using special logarithmic/graph paper.
Potency testing of the scorpion antivenom: The potency of the polyvalent scorpion antivenoms was assayed by the mixture of the antivenom and the venom(s) against which the antivenom was raised in different proportions keeping the concentration of either one constant. The mixtures were incubated at $37^{\circ} \mathrm{C}$ for 60 minutes, centrifuged and the supernatants injected intravenously into groups of 4 mice of uniform weight, age, sex and strain. The overnight mortality ( 24 hours) was determined. The mixture that contains the highest concentration of venom and does not kill the mice represents the neutralizing power of the antivenom (or its titer) against that venom.

Testing of abnormal toxicity: One $\mathrm{ml}$ of the undiluted antivenom solution was injected intraperitoneally into each of 5 mice weighing 17 $22 \mathrm{~g}$ and $5 \mathrm{ml}$ intraperitoneally into each of two guinea-pigs weighing between $250 \mathrm{~g}$ and $350 \mathrm{~g}$. The animals are observed over a period of 7 days. The animals were observed for any signs of ill health within the indicated time.

Testing of pyrogen: The test was carried out according to the British Pharmacopeia 1993. The aim of this test was to measure the rise in body temperature evoked in rabbits by the antivenom injection of a sterile solution of the substance to be examined.

In this test, two groups of rabbits (each group consists of 3 rabbits) were chosen for the test. The rabbits were kept individually in a quiet area with an appropriate uniform temperature. The test was carried out in a quiet room with no risk of disturbance or exciting the animals. Food was withheld overnight and until the test was completed, and water withheld during the test. The animals were retained in rabbit restraining cages only by loosely-fitting neck stocks; the rest of the body remained relatively free so that the rabbits may sit in a normal position.

Before 24 hours of testing the rabbits were treated with intravenous injection of $10 \mathrm{~mL}$ per kilogram of body mass of a pyrogen-free 9 $\mathrm{g} / \mathrm{L}$ solution of sodium chloride $\mathrm{R}$ which was warmed to $38.5^{\circ} \mathrm{C}$. The temperature was recorded by using a thermometer with a precision of $0.1^{\circ} \mathrm{C}$ precision. Measurements began $90 \mathrm{~min}$ before injection into the marginal vein of the ear of each rabbit over a period of 3 minutes. The temperature was recorded and continuing for $3 \mathrm{~h}$ after the injection of the solution.

In the main test, and for the first group, the antivenom samples could warm to $38.5^{\circ} \mathrm{C}$ before injection. Each rabbit was injected with the antivenom that was stored at real time storage condition $\left(3 \pm 2^{\circ} \mathrm{C}\right)$ in the same position as stated above. The antivenom volume was $0.5 \mathrm{ml}$ per $\mathrm{kg}$ of body mass. The second group was injected with antivenom sample that was stored at accelerated storage condition $\left(25 \pm 3^{\circ} \mathrm{C}\right.$, RH75\%.).

To perform this test, appropriate probes that were connected to APT 91 automatic pyrogen testing equipment were inserted in the rabbit rectal into a depth of $5 \mathrm{~cm}$ and rectal temperature was monitored in the pretests and the actual tests.

Test of sterility: A filter unit is properly assembled and sterilized prior to use. The contents of the prescribed number of ampoules were transferred to filter assembly under strict aseptic conditions. The contents of the ampoules were filtered with the aid of a pressure. The membranes were removed aseptically. One of the membranes was placed in $100 \mathrm{ml}$ of FTM and the other one in $100 \mathrm{ml}$ of TSB. The FTM media was incubated at $30-35^{\circ} \mathrm{C}$ and TSB at $20-25^{\circ} \mathrm{C}$ for 14 days only. The media were examined for macroscopic evidence of microbial growth at the $3^{\text {rd }}, 7^{\text {th }}, 10^{\text {th }}$ and $14^{\text {th }}$ days of incubation. Positive control of culture media as well as negative control tests were carried out using the same procedure. 
Citation: Elhag DE, Mahmoud RAK (2017) Efficacy and Stability of Scorpion Antivenom: At Different Storage Conditions. Pharm Anal Acta 8: 570. doi: $10.4172 / 2153-2435.1000570$

Page 3 of 6

\section{Results}

$\mathrm{pH}$ test: $\mathrm{pH}$ measurements of the randomly selected ampoules after being subjected to two different storage conditions (real and accelerated) showed that the values were comparable and within the limits of the acceptable range indicated for the produced antivenom. WHO requirement to produce antivenoms, stated the $\mathrm{PH}$ of the antivenom product should be in the range of 6-7 (Table 1).

Measurements of m-cresol content of ampoules was previously stored at the appropriate storage condition (real, $3 \pm 2^{\circ} \mathrm{C}$ ) and at accelerated condition $\left(25 \pm 3^{\circ} \mathrm{C}, \mathrm{RH} 75 \%\right)$. showed that there was a minor change in $\mathrm{m}$-cresol concentration, but this change was neither significant nor out of the range of the acceptable limits that was indicated on the pamphlet of the ampoules (Table 2).

Measuring the protein content of the polyvalent scorpion antivenom obtained randomly from the batch and kept at the two selected storage conditions real time storage condition $\left(3 \pm 2^{\circ} \mathrm{C}\right)$ and accelerated storage condition $\left(25 \pm 3^{\circ} \mathrm{C}, \mathrm{RH} 75 \%\right)$. showed that the protein content in the two sample classes were comparable (Table 3 ). The WHO guidelines states that he total concentration of proteins in antivenoms should preferably not exceed $10 \mathrm{~g} / \mathrm{dl}$, unless a higher protein content is justified and authorized by the competent authority.

\section{Pharmacological studies}

Determination of LD50: When Leiurus quinquestriatus (Lq) scorpion venom was injected into mice in gradually increasing doses ranging between 0.15 and $0.325 \mathrm{mgKg}^{-1}$ intravenously the LD50 was found to be $0.25+0.02 \mathrm{mgKg}^{-1}$. See Table 4 .

All animals injected with the venom showed signs of scorpion envenomation which included, fighting behavior, lacrymation, hyper

\begin{tabular}{|c|c|c|}
\hline Ampoule Number & Real time condition & Accelerated condition \\
\hline 1 & 6.274 & 6.132 \\
2 & 6.31 & 6.155 \\
3 & 6.281 & 6.142 \\
4 & 6.75 & 6.211 \\
5 & 6.283 & 6.152 \\
6 & 6.271 & 6.151 \\
\hline
\end{tabular}

Table 1: $\mathrm{PH}$ measures of polyvalent scorpion antivenom (Psc $91 \mathrm{H})$ subjected to real time storage condition $\left(3 \pm 2^{\circ} \mathrm{C}\right)$ and accelerated storage condition $\left(25 \pm 3^{\circ} \mathrm{C}\right.$, $\mathrm{RH} 75 \%)$.

\begin{tabular}{|c|c|c|}
\hline $\begin{array}{c}\text { Ampoule } \\
\text { No }\end{array}$ & $\begin{array}{l}\text { Real time condition }\left(3 \pm 2^{\circ} \mathrm{C}\right) \\
\text { concentration }(\mathrm{mg} / \mathrm{ml})\end{array}$ & $\begin{array}{l}\text { Accelerated condition }\left(25 \pm 3^{\circ} \mathrm{C} \text {, }\right. \\
\mathrm{RH} 75 \%) \text {. concentration }(\mathrm{mg} / \mathrm{ml})\end{array}$ \\
\hline 1 & 3.05 & 2.95 \\
\hline 2 & 2.99 & 2.94 \\
\hline 3 & 3.01 & 2.92 \\
\hline 4 & 3.05 & 2.94 \\
\hline 5 & 2.99 & 2.95 \\
\hline 6 & 3.01 & 2.92 \\
\hline
\end{tabular}

Table 2: $\mathrm{m}$-cresol concentration $(\mathrm{mg} / \mathrm{ml})$ in Psc $91 \mathrm{H}$ scorpion antivenom subjected to real time storage condition $\left(3 \pm 2^{\circ} \mathrm{C}\right)$ and accelerated storage condition $(25 \pm$ $3^{\circ} \mathrm{C}, \mathrm{RH} 75 \%$ )

\begin{tabular}{|c|c|c|}
\hline $\begin{array}{c}\text { Ampoule } \\
\text { No. }\end{array}$ & $\begin{array}{c}\text { Real time condition }(\mathbf{3} \mathbf{\pm} \\
\left.\mathbf{2}^{\circ} \mathbf{C}\right) \text { concentration }(\mathbf{m g} / \mathbf{m l})\end{array}$ & $\begin{array}{c}\text { Accelerated condition }\left(\mathbf{2 5} \mathbf{\pm} \mathbf{3}^{\circ} \mathbf{C} \text {, }\right. \\
\mathbf{R H 7 5} \%) \text { concentration } \mathbf{( m g} / \mathbf{m l})\end{array}$ \\
\hline 1 & 6.88 & 6.54 \\
2 & 6.33 & 6.31 \\
3 & 6.36 & 7.06 \\
4 & 7.04 & 7.29 \\
5 & 6.52 & 6.63 \\
6 & 6.58 & 7.27 \\
\hline
\end{tabular}

Table 3: Protein concentration $(\mathrm{mg} / \mathrm{dl})$ in Psc $91 \mathrm{H}$ scorpion antivenom subjected to real time storage condition $\left(3 \pm 2^{\circ} \mathrm{C}\right)$ and accelerated storage condition (25 \pm $\left.3^{\circ} \mathrm{C}, \mathrm{RH} 75 \%\right)$. salivation, micturation, defecation, increased respiration, tremor and occasional convulsion. Before death, the animal exhibited decreased motor activity, depressed respiration, gasping and convulsion. Post mortem macroscopical examination of the hearts and lungs showed cardiac arrest in systole with congestion of the heart in addition to hemorrhagic patches in the lung.

Testing the potency of the antivenom: When the potency of the used antivenom (Psc 91 H) was tested against Lq venom it was found that the titer of the antivenom is similar to that indicated in the pamphlet of the product. At the LD50 of 55 the venom was neutralized, and all the injected mice were survived (4 out of 4 mice injected). At higher doses (60 LD50) only $50 \%$ of the injected mice survived ( 2 out of 4 mice injected) in higher doses (65 LD50) none of the injected mice survived see Table 5 .

The results obtained by titrating the antivenom batches at different at accelerated condition $\left(25 \pm 3^{\circ} \mathrm{C}, \mathrm{RH} 75 \%\right)$ are shown in Table 6 .

Testing of abnormal toxicity of antivenom: Testing the abnormal toxicity of the product resulted in insignificant outcome since none of the injected mice ( 5 mice per group) or guinea pigs ( 2 guinea pig per group) showed any signs of ill health for the whole monitored time ( 7 days). All animals survived and were healthy by the end of the experiment. Comparing the effect of sample stored at real condition $\left(3 \pm 2^{\circ} \mathrm{C}\right)$, to that subjected to the accelerated condition $\left(25 \pm 3^{\circ} \mathrm{C}\right.$ RH75\%) gave no significant difference. See Tables 7 and 8.

\section{Testing the presence of pyrogenic material}

Measurements: The average measured temperature of first

\begin{tabular}{|c|c|c|c|}
\hline Group & $\begin{array}{c}\text { LQ Dose } \\
{\text { ( } \mathbf{m g ~ K}^{-1} \mathbf{~}}\end{array}$ & $\begin{array}{c}\text { Number of dead } \\
\text { mice }\end{array}$ & Dead \% of mice \\
\hline 1 & 0.150 & 0 & 0 \\
2 & 0.175 & 1 & 10 \\
3 & 0.200 & 2 & 20 \\
4 & 0,225 & 4 & 40 \\
5 & 0.250 & 5 & 50 \\
6 & 0.275 & 7 & 70 \\
7 & 0.300 & 9 & 90 \\
8 & 0.325 & 10 & 100 \\
\hline
\end{tabular}

Table 4: Determination of intravenous LD50 of Leiurus quinquestriatus scorpion venom.

\begin{tabular}{|c|c|c|c|c|c|c|c|c|c|c|}
\hline \multirow{2}{*}{$\begin{array}{c}\text { Ampoule } \\
\text { No. }\end{array}$} & \multicolumn{9}{|c|}{ Dose of venom $\mathbf{( L D}_{\mathbf{5 0}}$ /mI) } \\
\cline { 2 - 11 } & $\mathbf{4 5}$ & \multicolumn{2}{|c|}{$\mathbf{5 0}$} & \multicolumn{2}{c|}{$\mathbf{5 5}$} & \multicolumn{2}{c|}{$\mathbf{6 0}$} & \multicolumn{2}{c|}{$\mathbf{6 5}$} \\
\hline & Alive & Dead & Alive & Dead & Alive & Dead & Alive & Dead & Alive & Dead \\
\hline 1 & 4 & 0 & 4 & 0 & 4 & 0 & 2 & 2 & 0 & 4 \\
2 & 4 & 0 & 4 & 0 & 4 & 0 & 2 & 2 & 0 & 4 \\
3 & 4 & 0 & 4 & 0 & 4 & 0 & 2 & 2 & 0 & 4 \\
4 & 4 & 0 & 4 & 0 & 4 & 0 & 1 & 3 & 0 & 4 \\
5 & 4 & 0 & 4 & 0 & 4 & 0 & 2 & 2 & 0 & 4 \\
6 & 4 & 0 & 4 & 0 & 4 & 0 & 1 & 3 & 0 & 4 \\
\hline
\end{tabular}

Table 5: Potency of Psc $91 \mathrm{H}$ polyvalent scorpion antivenom stored at rea condition $\left(3 \pm 2^{\circ} \mathrm{C}\right)$.

\begin{tabular}{|c|c|c|c|c|c|c|c|c|c|c|}
\hline \multirow{2}{*}{$\begin{array}{c}\text { Ampoule } \\
\text { No. }\end{array}$} & \multicolumn{9}{c|}{ Dose of venom $\mathbf{( L D}_{\mathbf{5 0}}$ /ml) } \\
\cline { 2 - 11 } & $\mathbf{4 5}$ & \multicolumn{2}{|c|}{$\mathbf{5 0}$} & \multicolumn{2}{c|}{$\mathbf{5 5}$} & \multicolumn{2}{c|}{$\mathbf{6 0}$} & \multicolumn{2}{c|}{$\mathbf{6 5}$} \\
\hline & Alive & Dead & Alive & Dead & Alive & Dead & Alive & Dead & Alive & Dead \\
\hline 1 & 4 & 0 & 4 & 0 & 4 & 0 & 1 & 3 & 0 & 4 \\
2 & 4 & 0 & 4 & 0 & 4 & 0 & 2 & 2 & 0 & 4 \\
3 & 4 & 0 & 4 & 0 & 4 & 0 & 1 & 3 & 0 & 4 \\
4 & 4 & 0 & 4 & 0 & 4 & 0 & 1 & 3 & 0 & 4 \\
5 & 4 & 0 & 4 & 0 & 4 & 0 & 2 & 2 & 0 & 4 \\
6 & 4 & 0 & 4 & 0 & 4 & 0 & 1 & 3 & 0 & 4 \\
\hline
\end{tabular}

Table 6: Potency of Psc $91 \mathrm{H}$ polyvalent scorpion antivenom stored at accelerated condition $\left(25 \pm 3^{\circ} \mathrm{C}, \mathrm{RH} 75 \%\right)$. 


\begin{tabular}{|c|c|c|c|c|c|c|c|c|c|c|c|c|c|c|}
\hline \multirow{3}{*}{$\begin{array}{l}\text { Guinea. } \\
\text { Pig no. }\end{array}$} & \multicolumn{14}{|c|}{ Days } \\
\hline & \multicolumn{2}{|c|}{1} & \multicolumn{2}{|c|}{2} & \multicolumn{2}{|c|}{3} & \multicolumn{2}{|c|}{4} & \multicolumn{2}{|c|}{5} & \multicolumn{2}{|c|}{6} & \multicolumn{2}{|c|}{7} \\
\hline & real & Acc. & real & Acc. & real & Acc. & real & Acc. & real & Acc. & real & Acc. & real & Acc. \\
\hline $\begin{array}{l}1 \\
2\end{array}$ & $\begin{array}{l}\mathrm{NI} \\
\mathrm{NI}\end{array}$ & $\begin{array}{l}\mathrm{NI} \\
\mathrm{NI}\end{array}$ & $\begin{array}{l}\mathrm{NI} \\
\mathrm{NI}\end{array}$ & $\begin{array}{l}\mathrm{NI} \\
\mathrm{NI}\end{array}$ & $\begin{array}{l}\mathrm{NI} \\
\mathrm{NI}\end{array}$ & $\begin{array}{l}\mathrm{NI} \\
\mathrm{NI}\end{array}$ & $\begin{array}{l}\mathrm{NI} \\
\mathrm{NI}\end{array}$ & $\begin{array}{l}\mathrm{NI} \\
\mathrm{NI}\end{array}$ & $\begin{array}{l}\mathrm{NI} \\
\mathrm{NI}\end{array}$ & $\begin{array}{l}\mathrm{NI} \\
\mathrm{NI}\end{array}$ & $\begin{array}{l}\mathrm{NI} \\
\mathrm{NI}\end{array}$ & $\begin{array}{l}\mathrm{NI} \\
\mathrm{NI}\end{array}$ & $\begin{array}{l}\mathrm{NI} \\
\mathrm{NI}\end{array}$ & $\begin{array}{l}\mathrm{NI} \\
\mathrm{NI}\end{array}$ \\
\hline
\end{tabular}

Table 7: Abnormal toxicity result of monitoring guinea pigs injected with $\mathrm{Psc} 91 \mathrm{H}$ scorpion antivenom that was subjected to real time storage condition $\left(3 \pm 2^{\circ} \mathrm{C}\right)$ and accelerated storage condition $\left(25 \pm 3^{\circ} \mathrm{C}, \mathrm{RH} 75 \%\right)$.

\begin{tabular}{|c|c|c|c|c|c|c|c|c|c|c|c|c|c|c|}
\hline \multirow{3}{*}{$\begin{array}{c}\text { Amp. } \\
\text { No. }\end{array}$} & \multicolumn{14}{|c|}{ Days } \\
\hline & \multicolumn{2}{|c|}{1} & \multicolumn{2}{|c|}{2} & \multicolumn{2}{|c|}{3} & \multicolumn{2}{|c|}{4} & \multicolumn{2}{|c|}{5} & \multicolumn{2}{|c|}{6} & \multicolumn{2}{|c|}{7} \\
\hline & Real & Acc. & real & Acc. & Real & Acc. & real & Acc. & real & Acc. & real & Acc. & real & Acc. \\
\hline 1 & $\mathrm{NI}$ & $\mathrm{NI}$ & $\mathrm{NI}$ & $\mathrm{NI}$ & $\mathrm{NI}$ & $\mathrm{NI}$ & $\mathrm{NI}$ & $\mathrm{NI}$ & $\mathrm{NI}$ & $\mathrm{NI}$ & $\mathrm{NI}$ & $\mathrm{NI}$ & $\mathrm{NI}$ & $\mathrm{NI}$ \\
\hline 2 & $\mathrm{NI}$ & $\mathrm{NI}$ & $\mathrm{NI}$ & $\mathrm{NI}$ & $\mathrm{NI}$ & $\mathrm{NI}$ & $\mathrm{NI}$ & $\mathrm{NI}$ & $\mathrm{NI}$ & $\mathrm{NI}$ & $\mathrm{NI}$ & $\mathrm{NI}$ & $\mathrm{NI}$ & $\mathrm{NI}$ \\
\hline 3 & $\mathrm{NI}$ & $\mathrm{NI}$ & $\mathrm{NI}$ & $\mathrm{NI}$ & $\mathrm{NI}$ & $\mathrm{NI}$ & $\mathrm{NI}$ & $\mathrm{NI}$ & $\mathrm{NI}$ & $\mathrm{NI}$ & $\mathrm{NI}$ & $\mathrm{NI}$ & $\mathrm{NI}$ & $\mathrm{NI}$ \\
\hline 4 & $\mathrm{NI}$ & $\mathrm{NI}$ & $\mathrm{NI}$ & $\mathrm{NI}$ & $\mathrm{NI}$ & $\mathrm{NI}$ & $\mathrm{NI}$ & $\mathrm{NI}$ & $\mathrm{NI}$ & $\mathrm{NI}$ & $\mathrm{NI}$ & $\mathrm{NI}$ & $\mathrm{NI}$ & $\mathrm{NI}$ \\
\hline 5 & $\mathrm{NI}$ & $\mathrm{NI}$ & $\mathrm{NI}$ & $\mathrm{NI}$ & $\mathrm{NI}$ & $\mathrm{NI}$ & $\mathrm{NI}$ & $\mathrm{NI}$ & $\mathrm{NI}$ & $\mathrm{NI}$ & $\mathrm{NI}$ & $\mathrm{NI}$ & $\mathrm{NI}$ & $\mathrm{NI}$ \\
\hline 6 & $\mathrm{NI}$ & $\mathrm{NI}$ & $\mathrm{NI}$ & $\mathrm{NI}$ & $\mathrm{NI}$ & $\mathrm{NI}$ & $\mathrm{NI}$ & $\mathrm{NI}$ & $\mathrm{NI}$ & $\mathrm{NI}$ & $\mathrm{NI}$ & $\mathrm{NI}$ & $\mathrm{NI}$ & $\mathrm{NI}$ \\
\hline
\end{tabular}

Table 8: Abnormal toxicity result of monitoring mice injected with $\mathrm{Psc} 91 \mathrm{H}$ scorpion antivenom that was subjected to real time storage condition $\left(3 \pm 2^{\circ} \mathrm{C}\right)$ and accelerated storage condition $\left(25 \pm 3^{\circ} \mathrm{C}, \mathrm{RH} 75 \%\right)$.

group in which the rabbits were injected with the antivenom stored at real time storage condition $\left(3+20^{\circ} \mathrm{C}\right)$ before and after the test were $38,20^{\circ} \mathrm{C}$ and $38,60^{\circ} \mathrm{C}$ before and after the test, respectively. Regarding the second group in which the rabbits were injected with the antivenom stored accelerated storage condition $(25 \pm$ $3^{\circ} \mathrm{C}, \mathrm{RH} 75 \%$.) the measured temperature was $38,3^{\circ} \mathrm{C}$ and $38,7^{\circ} \mathrm{C}$ before and after the test, respectively. No significant rising in body temperature when the rabbits were injected with the antivenom that was subjected to real time storage condition $\left(3 \pm 2^{\circ} \mathrm{C}\right)$ and accelerated storage condition $\left(25 \pm 3^{\circ} \mathrm{C}, \mathrm{RH} 75 \%\right)$.

Testing of the sterility of the product: When the sterility of antivenom product that was kept at the two selected storage conditions real time storage condition $\left(3 \pm 2^{\circ} \mathrm{C}\right)$ and accelerated storage condition $\left(25 \pm 3^{\circ} \mathrm{C}, \mathrm{RH} 75 \%\right.$ the results was found to be satisfactory. No bacterial growth was detected in the incubated samples after 14 days indicating the sterility of the product at the two different storage conditions.

\section{Discussion}

\section{Chemical tests}

In the present study the $\mathrm{pH}$ values of the product tested was found to be in the acceptable ranges. WHO requirement to produce antivenoms, stated the $\mathrm{pH}$ of the antivenom product should be in the range of 6-7. In several occasions It was recommended that the $\mathrm{pH}$ of any intravenously injectable product to be in this range since the nearer the $\mathrm{PH}$ value to 7.4 the less the damage that can occur for the cells of the blood [21].

Testing the preservative $\mathrm{m}$ - cresol content in the antivenom Psc $91 \mathrm{H}$ stored in two different storage conditions real time storage condition $\left(3 \pm 2^{\circ} \mathrm{C}\right)$ and accelerated storage condition $\left(25 \pm 3^{\circ} \mathrm{C}\right.$, $\mathrm{RH} 75 \%$. indicated that there was a slight difference between the results of the two conditions, nevertheless, both results were in the acceptable limits. It is well known that $\mathrm{m}$ - cresol as a phenolic compound is greatly affected by drastic conditions such as light and high temperature [22]. In this regard, no stated recommendation was found in British pharmacopoeias regarding the actual concentration that must be used in such preparation. It is also well known that high temperatures promote aggregation and formation and protein precipitates which is an important indicator of instability [22-25]. In the present study evaluating protein content in the scorpion antivenom presents an amount of less than $2 \%$ in samples obtained at the two different storage conditions real time storage condition $\left(3 \pm 2^{\circ} \mathrm{C}\right)$ and accelerated storage condition $\left(25 \pm 3^{\circ} \mathrm{C}, \mathrm{RH} 75 \%\right)$.

Investigation of albumin content revealed no signs of albumin presence in samples kept at either real-time condition real time storage condition $\left(3 \pm 2^{\circ} \mathrm{C}\right)$ or subjected to and accelerated storage condition $\left(25 \pm 3^{\circ} \mathrm{C}, \mathrm{RH} 75 \%\right)$. A study conducted by. Nudel et al. concluded that the presence of albumin could affect the efficacy of the antivenom altering its ability to complex with the venom [26]. However, it is well known that the factors which may influence the presence and precipitation of albumin include caprylic acid concentration, plasma $\mathrm{pH}$ and temperature. The effect of these three factors on albumin concentration was assessed in terms of filtration speed, residual albumin, total protein content and turbidity. The results presented here give evidence that the three variables are involved in the precipitation process. Since the antivenom products are used intravenously, the care of the manufacturers is to reduce the albumin content of their products as much as possible [26]. In the present study, albumin content was almost not present and different storage conditions did not show any appearance of albumin in the tested samples. The WHO guidelines states that he total concentration of proteins in antivenoms should preferably not exceed $10 \mathrm{~g} / \mathrm{dl}$, unless a higher protein content is justified and authorized by the competent authority.

\section{Pharmacological tests}

The value of the intravenous injection of Leiurus quinquestriatus venom obtained in this study was comparable to findings of several investigator $[27,28]$. Oukkache et al. stated that as part of the combat, appropriate assessment of scorpion and snake venom 50\% lethal doses (LD50) is an important step for an accurate evaluation of the toxic activity of specific venoms, and is also regularly used to select the relevant antivenom batch, as well as to establish the neutralizing capacity of vials $[18,29]$.

Regarding the potency test applied in the present study, the neutralization power was determined to be $55 \mathrm{LD} 50$. That means that the antivenom was able to neutralize 55 LD50 of Leiurus quinquestriatus scorpion venom and at the same time preventing $L$. quinquestriatus scorpionism. The used antivenom had strong titration potency which is enough to neutralize the venom present in the blood of the victim and at the same time quite enough to neutralize the lethal dose of the venom in the tested animals. This neutralization was obtained in the form of increasing survival time, protecting animal from death and at 
the same time it masked any abnormal toxicity signs of envenomation that could be noticed in the injected mice.

Monitoring the effects of antivenom taken from both types of samples i.e. real-time storage condition $\left(3 \pm 2^{\circ} \mathrm{C}\right)$ and accelerated storage condition $\left(25 \pm 3^{\circ} \mathrm{C}, \mathrm{RH} 75 \%\right.$ on the animals tested for occurrence of any abnormal toxic effects gave negative signs of toxicity. All tested animals showed good health signs, normal behaviors and death was not reported to occur as well. The animals in both groups of guinea pigs and mice survived for the whole length of the experiment $(7$ days) with good health status after being injected with the appropriate doses. This effect may be explained by the high purity of antivenom and appropriate doses given to the test animals. Chippaux [30] reported that improved purification of the antivenom by using immunoglobulin fragments in the production has led to increased tolerance and efficiency of antivenom at the same time result in clear elimination of possible toxicity signs.

Testing the presence of pyrogenic material revealed that no significant increase in body temperature of tested animals appeared on the two group rabbits injected with samples kept at real time storage condition $\left(3 \pm 2^{\circ} \mathrm{C}\right)$ and accelerated storage condition $\left(25 \pm 3^{\circ} \mathrm{C}\right.$, RH75\%. However, antivenom contamination by endotoxins is the main cause of pyrogenic reactions in patients. Endotoxins present strong biological effects on humans and other mammals when reach their bloodstream during bacterial infection or via intravenous application of a contaminated medicine. However, increasing antivenom purity can enhance the therapeutic effect and would help in general avoid the presence of foreign matter that could possibly lead to the unwanted effect of pyrogenicity. Unfortunately, the incorporation of refined purification techniques to antivenom production process had resulted in cost increase [31-34].

It is ethically agreed that sterility is an expected quality of injectable drug products including antivenoms by their intended use. Therefore, injectable drug products assert to be sterile and are subject to many sterility testings before it is used for human being. In the present study, and when performing the sterility test on the samples kept at the two different storage conditions, and after completing the incubation time of 14 days, both samples of under real time storage condition $(3 \pm$ $\left.2^{\circ} \mathrm{C}\right)$ and accelerated storage condition $\left(25 \pm 3^{\circ} \mathrm{C}, \mathrm{RH} 75 \%\right)$ showed no microbial growth. This result confirms the sterility of the antivenom product stored at the different storage conditions. The presence of $\mathrm{m}$-cresol as preservative and in proper concentrations helped in maintaining the sterility of the product in different conditions real time storage condition $\left(3 \pm 2^{\circ} \mathrm{C}\right)$ and accelerated storage condition $(25 \pm$ $3^{\circ} \mathrm{C}, \mathrm{RH} 75 \%$ ).

\section{Conclusion}

The present work suggested that keeping the antivenom at the specified temperature and humidity and upon exposure to light for longer period does not affect the antivenom in term of its sterility or efficacy.

\section{References}

1. Torabi E, Behdani M, Chafi MH, Moazzami R, Sabatier JM, et al. (2017) Characteristics and Lethality of a Novel Recombinant Dermonecrotic Venom Phospholipase D from Hemiscorpius lepturus. Toxins 9

2. Ferreira MG, Duarte CG, Oliveira MS, Castro KLP, Teixeira MS, et al. (2016) Toxicity of crude and detoxified Tityus serrulatus venom in anti-venomproducing sheep. J Vet Sci 17: 467-477.

3. Chippaux JP (2012) Emerging options for the management of scorpion stings Drug Des Devel Ther 6: 165-173.
4. Skolnik AB, Ewald MB (2013) Pediatric scorpion envenomation in the United States: morbidity, mortality, and therapeutic innovations. Pediatr Emerg Care 29: 98-103.

5. Rodrigo C, Gnanathasan A (2017) Management of scorpion envenoming: systematic review and meta-analysis of controlled clinical trials. Syst Rev 6: 74

6. Abroug F, ElAtrous S, Nouira S, Haguiga H, Touzi N, et al. (1999) Serotherapy in scorpion envenomation: a randomised controlled trial. Lancet Lond Engl 354 906-909.

7. Bosmans F, Tytgat $J$ (2007) Sea anemone venom as a source of insecticida peptides acting on voltage-gated $\mathrm{Na}+$ channels. Toxicon off $\mathrm{J}$ Int Soc Toxinology 49: 550-560.

8. Bucaretchi F, De Capitani EM, Fernandes CB, Santos TM, Zamilute IAG, et al. (2016) Fatal ischemic stroke following Tityus serrulatus scorpion sting in a patient with essential thrombocythemia. Clin Toxicol Phila Pa 54: 867-870.

9. Cupo P, Figueiredo AB, Filho AP, Pintya AO, Tavares Júnior GA, et al. (2007) Acute left ventricular dysfunction of severe scorpion envenomation is related to myocardial perfusion disturbance. Int J Cardiol 116: 98-106.

10. Cheng AC, Winkel KD (2004) Antivenom efficacy, safety and availability: measuring smoke. The Med J Aus 180: 5-6.

11. Ayari-Riabi S, Trimaille T, Mabrouk K, Bertin D, Gigmes D, et al. (2016) Venom conjugated polylactide applied as biocompatible material for passive and active immunotherapy against scorpion envenomation. Vaccine 34: 1810-1815.

12. Haddad-Ishak-Boushaki W, Laraba-Djebari F (2017) Age-Related Changes in Inflammatory Response after Experimental Envenomation: Impact on the Susceptibility to Androctonus australis hector Venom. Inflammation 40: 1131-1142.

13. Bahloul M, Regaieg K, Chabchoub I, Kammoun M, Chtara K, et al. (2017) Severe scorpion envenomation: pathophysiology and the role of inflammation in multiple organ failure. Med Sante Trop 27: 214-221.

14. Petricevich VL (2010) Scorpion venom and the inflammatory response. Mediators Inflamm.

15. Burnouf T, Griffiths E, Padilla A, Seddik S, Stephano MA et al. (2004) Assessment of the viral safety of antivenoms fractionated from equine plasma. Biol J Int Assoc Biol Stand 32: 115-128.

16. Gutiérrez JM, Rojas E, Quesada L, León G, Núñez J, et al. (2005) Pan-African polyspecific antivenom produced by caprylic acid purification of horse lgG: an alternative to the antivenom crisis in Africa. Trans R Soc Trop Med Hyg 99: 468-475.

17. Engl N (2009) Antivenom for Children with Neurotoxicity from Scorpion Stings J Med 361: 631-632.

18. Oukkache N, El Jaoudi R, Ghalim N, Chgoury F, Bouhaouala B, et al. (2014) Evaluation of the lethal potency of scorpion and snake venoms and comparison between intraperitoneal and intravenous injection routes. Toxins 6: 1873-1881.

19. Berg RA, Tarantino MD (1991) Envenomation by the scorpion Centruroides exilicauda (C sculpturatus): severe and unusual manifestations. Pediatrics 87 930-933.

20. Solano S, Segura Á, León G, Gutiérrez JM, Burnouf T (2012) Low pH formulation of whole $\operatorname{lgG}$ antivenom: impact on quality, safety, neutralizing potency and viral inactivation. Biol J Int Assoc Biol Stand 40: 129-133.

21. Theakston RDG, Warrell DA, Griffiths E (2003) Report of a WHO workshop on the standardization and control of antivenoms. Toxicon off $J$ Int Soc Toxinology 41: $541-557$

22. Christensen PA (1975) The stability of refined antivenin. Toxicon off J Int Soc Toxinology 13: 75-77.

23. Tornberg E (2005) Effects of heat on meat proteins - Implications on structure and quality of meat products. Meat Sci 70: 493-508.

24. Rojas G, Espinoza M, Lomonte B, Gutiérrez JM (1990) Effect of storage temperature on the stability of the liquid polyvalent antivenom produced in Costa Rica. Toxicon off J Int Soc Toxinology 28: 101-105.

25. Gutiérrez JM, Fan HW, Silvera CLM, Angulo Y (2009) Stability, distribution and use of antivenoms for snakebite envenomation in Latin America: Report of a workshop. Toxicon 53: 625-630.

26. Nudel BC, Perdoménico C, lácono R, Cascone O (2012) Optimization by factorial analysis of caprylic acid precipitation of non-immunoglobulins from 
Citation: Elhag DE, Mahmoud RAK (2017) Efficacy and Stability of Scorpion Antivenom: At Different Storage Conditions. Pharm Anal Acta 8: 570. doi: $10.4172 / 2153-2435.1000570$

hyperimmune equine plasma for antivenom preparation. Toxicon off $\mathrm{J}$ Int Soc Toxinology 59: 68-73.

27. Fatani AJ, Harvey AL, Furman BL, Rowan EG (2000) The effects of lignocaine on actions of the venom from the yellow scorpion "Leiurus quinquestriatus" in vivo and in vitro. Toxicon off $\mathrm{J}$ Int Soc Toxinology 38: 1787-1801.

28. Ismail M, Al-Ahaidib MS, Abdoon N, Abd-Elsalam MA (2007) Preparation of a novel antivenom against Atractaspis and Walterinnesia venoms. Toxicon off $J$ Int Soc Toxinology 49: 8-18.

29. Oukkache N, Ahmad Rusmili MR, Othman I, Ghalim N, Chgoury F, et al. (2015) Comparison of the neurotoxic and myotoxic effects of two Moroccan scorpion venoms and their neutralization by experimental polyclonal antivenom. Life Sci 124: $1-7$.

30. Chippaux JP, Goyffon M (1998) Venoms, antivenoms and immunotherapy. Toxicon off J Int Soc Toxinology 36: 823-846.
31. Pandi K, Krishnamurthy S, Srinivasaraghavan R, Mahadevan S (2014) Efficacy of scorpion antivenom plus prazosin versus prazosin alone for Mesobuthus tamulus scorpion sting envenomation in children: a randomised controlled trial. Arch Dis Child 99: 575-580.

32. Bawaskar HS, Bawaskar PH (2001) Call for global snake-bite control and procurement funding. Lancet Lond Engl 357: 1132-1133.

33. Bawaskar HS (2011) Efficacy and safety of scorpion antivenom plus prazosin compared with prazosin alone for venomous scorpion (Mesobuthus tamulus) sting: randomised open label clinical trial. BMJ 342.

34. Kumar PMA, Krishnamurthy $S$, Srinivasaraghavan $R$, Mahadevan $S$ Harichandrakumar KT (2015) Predictors of Myocardial Dysfunction in Children with Indian Red Scorpion (Mesobuthus tamulus) Sting Envenomation. Indian Pediatr 52: 297-301. 